\section{Aroma Volatiles of Mature-green and Tree-ripe 'Tommy Atkins' Mangoes after Controlled Atmosphere vs. Air Storage}

\author{
R.J. Bender ${ }^{1}$ and J.K. Brecht ${ }^{2}$ \\ Horticultural Sciences Department, University of Florida, P.O. Box 110690 , \\ Gainesville, FL 32611-0690
}

E.A. Baldwin

U.S. Department of Agriculture, Agricultural Research Service, Citrus \& Subtropical Products Laboratory, P.O. Box 1909, Winter Haven, FL 33883-1909

\section{T.M.M. Malundo ${ }^{3}$ \\ Food Science and Technology Department, University of Georgia Experiment Station, Griffin, GA 30223-1797}

Additional index words. terpenes, acetaldehyde, ethanol, hexanal, Mangifera indica

\begin{abstract}
To determine the effects of fruit maturity, storage temperature, and controlled atmosphere (CA) on aroma volatiles, mature-green (MG) and tree-ripe (TR) 'Tommy Atkins' mangoes (Mangifera indica L.) were stored for 21 days in air or in $\mathrm{CA}\left(5 \% \mathrm{O}_{2}\right.$ plus $10 \%$ or $25 \% \mathrm{CO}_{2}$ ). The MG fruit were stored at $12{ }^{\circ} \mathrm{C}$ and the TR fruit at either 8 or $12{ }^{\circ} \mathrm{C}$. Homogenized mesocarp tissue from fruit that had ripened for 2 days in air at $20^{\circ} \mathrm{C}$ after the 21-day storage period was used for aroma volatile analysis. The TR mangoes produced much higher levels of all aroma volatiles except hexanal than did MG fruit. Both MG and TR mangoes stored in $25 \% \mathrm{CO}_{2}$ tended to have lower terpene (especially pcymene) and hexanal concentrations than did those stored in $10 \% \mathrm{CO}_{2}$ and air-stored fruit. Acetaldehyde and ethanol levels tended to be higher in TR mangoes from $25 \% \mathrm{CO}_{2}$ than in those from $10 \% \mathrm{CO}_{2}$ or air storage, especially at $8{ }^{\circ} \mathrm{C}$. Inhibition of volatile production by $25 \% \mathrm{CO}_{2}$ was greater in MG than in TR mangoes, and at $8^{\circ} \mathrm{C}$ compared to $12{ }^{\circ} \mathrm{C}$ for $\mathrm{TR}$ fruit. However, aroma volatile levels in $\mathrm{TR}$ mangoes from the $25 \% \mathrm{CO}_{2}$ treatment were in all cases equal to or greater than those in MG fruit treatments. The results suggest that properly selected atmospheres, which prolong mango shelf life by slowing ripening processes, can allow TR mangoes to be stored or shipped without sacrificing their superior aroma quality.
\end{abstract}

Intensified international trade in recent years has promoted mangoes to higher ranks of popularity (Gourgue et al., 1992; Subrahmanyam, 1990). Continuous availability on the market has changed the status of mango from that of a specialty fruit with unique flavor (Engel and Tressl, 1983) to a standard item in produce departments. This has been made possible by adoption of postharvest handling practices that enable the movement of larger volumes of fruit (Medlicott et al., 1986; Tucker and Seymour, 1991). Harvest of mature-green (MG) mangoes

Received for publication 3 May 1999. Accepted for publication 24 Sept. 1999. Florida Agricultural Experiment Station Journal Series No. R-06700. The cost of publishing this paper was defrayed in part by the payment of page charges. Under postal regulations, this paper therefore must be hereby marked advertisement solely to indicate this fact. ${ }^{1}$ Current address: Horticultura/Fac. AgronomiaUFRGS 91501-970 Porto Alegre/RS, Brazil.

${ }^{2}$ To whom reprint requests should be addressed. ${ }^{3}$ Current address: U.S. Distilled Products, 1607 S. 12th St., Princeton, MN 55371. prolongs shelf life (Thomas and Joshi, 1988), but also negatively affects flavor characteristics, as has already been demonstrated for apple (Malus $\times$ domestica Borkh.) (Streif and Bangerth, 1988; Willaert et al., 1983).

Lakshminarayana (1980) determined that mangoes harvested at the MG stage and then ripened at temperatures above $15{ }^{\circ} \mathrm{C}$ had better flavor than those held below $15{ }^{\circ} \mathrm{C}$. terize mango flavor components (Bartley and Schwede, 1987; Engel and Tressl, 1983; Koulibaly et al., 1992; MacLeod and Snyder, 1985). Engel and Tressl (1983) identified the monoterpenes as an important class of volatiles contributing to mango flavor in New World varieties, in contrast to Old World varieties, which have more oxygenated volatile compounds like esters, furanones, and sidered to be important contributors to the flavor of Florida (New World) mango varieties such as 'Keitt', 'Kent', and 'Tommy Atkins' (Malundo et al., 1996, 1997). The in those varieties were ethanol, acetaldehyde, Several attempts have been made to characlactones. The terpene hydrocarbons are cononly oxygenated volatile compounds found and hexanal (MacLeod and Snyder, 1985; Malundo et al., 1997).

Despite the extensive work conducted to identify the more than 150 volatile compounds found in various mango varieties, there has been no evaluation of changes in mango aroma profiles resulting from different storage conditions. Therefore, the objective of this study was to determine if temperature and ripeness stage could significantly influence the production of aroma volatiles by 'Tommy Atkins' mangoes held in air or controlled atmosphere (CA) storage.

\section{Materials and Methods}

Mature-green and tree-ripe (TR) 'Tommy Atkins' mangoes were harvested from a grove in Homestead, Fla., stored overnight at $12{ }^{\circ} \mathrm{C}$, then transported by car to Gainesville and placed in a flow-through CA system at 8 (TR) or $12{ }^{\circ} \mathrm{C}$ (MG and TR) with the following treatments: 1 ) air; 2) $5 \% \mathrm{O}_{2}$ plus $10 \% \mathrm{CO}_{2}\left(=10 \% \mathrm{CO}_{2}\right)$; and 3) $5 \% \mathrm{O}_{2}$ plus $25 \% \mathrm{CO}_{2}\left(=25 \% \mathrm{CO}_{2}\right)$. Each treatment was replicated three times, with each replicate consisting of four fruit in a $10.05-\mathrm{L}$ sealed glass jar with inlet and outlet tubes for gas flow. Ripeness stages for the MG and TR fruit corresponded to RS1 (fruit hard, well formed, with totally green skin ground color) and RS3 (fruit firm, well formed, with some yellow ground color development), respectively, as described in Miller et al. (1986).

Aroma volatiles were measured in mango mesocarp tissue after $2 \mathrm{~d}$ in air at $20^{\circ} \mathrm{C}$ following a $21-\mathrm{d}$ storage period at 8 or $12^{\circ} \mathrm{C}$. Mesocarp tissue was homogenized with equal parts of deionized water and the diluted homogenate was stored at $-20{ }^{\circ} \mathrm{C}$ until used for volatile determinations. Volatile components were quantified based on the headspace analysis procedure of Baldwin et al. (1991) as modified by Malundo et al. (1997) for mangoes. Analysis was conducted with a Perkin-Elmer model 8500 FID gas chromatograph with model HS-5 headspace sampler (Perkin-Elmer; Foster City, Calif.), and a $0.53 \times 3000 \mathrm{~mm}$ polar Durowax column (J\&W Scientific, Folsom, Calif.) The concentrations of the hydrocarbon terpene volatiles ( $\alpha$-pinene, 3 carene, limonene, and p-cymene) were calculated as $\mu \mathrm{L} \cdot \mathrm{L}^{-1}$ using regression equations fitted to peak height calibration curves as described in Malundo et al. (1997). Data for acetaldehyde, ethanol, and hexanal levels are presented as peak heights.

The experiment was conducted twice with 'Tommy Atkins' and once each with 'Haden' and 'Keitt' mangoes (data not shown) with similar results. The experimental design was completely randomized, with MG fruit stored in three atmosphere treatments at $12{ }^{\circ} \mathrm{C}$ and TR fruit stored in the same atmospheres at either 8 or $12^{\circ} \mathrm{C}$. Data were analyzed [analysis of variance (ANOVA) and least significant difference (LSD)] using SAS for PC (SAS Inst., Cary, N.C.). The results for MG and TR fruit stored at $12{ }^{\circ} \mathrm{C}$ and for TR fruit held at 8 and $12{ }^{\circ} \mathrm{C}$ were analyzed as separate data sets and the overall LSD values were calculated at $P \leq 0.05$ for comparisons of the treatments. 


\section{Results and Discussion}

The concentrations of all four of the terpene volatiles measured were influenced by initial ripeness stage, with $\mathrm{MG}$ fruit from all atmosphere treatments stored at $12{ }^{\circ} \mathrm{C}$ having lower concentrations than did TR mangoes stored at the same temperature (Table 1). However, there was no significant temperature effect on the levels of the terpene volatiles $\alpha$-pinene, 3-carene, and limonene for TR mangoes stored at 8 or $12{ }^{\circ} \mathrm{C}$ (Table 1). The only terpene in TR fruit that was significantly affected by the storage temperature was pcymene, which was present at higher levels after $12{ }^{\circ} \mathrm{C}$ storage than after $8{ }^{\circ} \mathrm{C}$ storage. Terpene concentrations also seemed to be influenced by $\mathrm{CO}_{2}$ concentration (Table 1). There was a tendency for the concentrations of the terpenes to be lower with increasing $\mathrm{CO}_{2}$ concentration in the storage atmosphere at both temperatures and for both ripeness stages. CA storage, especially the $25 \% \mathrm{CO}_{2}$ treatment, seemed to reduce terpene biosynthesis regardless of ripeness stage. However, the terpene aroma volatile levels in TR mangoes from the $25 \% \mathrm{CO}_{2}$ treatment at $12{ }^{\circ} \mathrm{C}$, while lower than the levels in the $10 \% \mathrm{CO}_{2}$ or air treatments at $12{ }^{\circ} \mathrm{C}$, were still significantly greater than those in $\mathrm{MG}$ fruit stored in either air or CA at $12^{\circ} \mathrm{C}$.

Based on subjective evaluations, Engel and Tressl (1983) concluded that monoterpenes are important components of mango flavor, especially for Florida varieties. Wilson et al. (1990) also suggested that, because of the complexity of mango flavor, there is no typical flavor component for mangoes. As for the metabolic processes leading to volatile biosynthesis, lipid components have been considered to be the main precursors of volatiles in mangoes and in fruits in general via their breakdown to fatty acids in the mevalonate and isoprenoid pathways (Gholap and Bandyopadhyay, 1980; Koulibaly et al., 1992; Selvaraj et al., 1989).

Gholap and Bandyopadhyay (1980) identified significant changes in fatty acid ratios in ripening mangoes. The authors suggested that these fatty acid components might have a significant metabolic function in ripening. Therefore, the effects of storage atmospheres on 'Tommy Atkins' aroma components could be related to the effects of $\mathrm{CO}_{2}$-mediated ripening retardation, resulting in delay of onset of ripening in $\mathrm{MG}$ and reduced rate of ripening in TR mangoes.

Despite the relatively high acetaldehyde and ethanol levels in TR mangoes from the $25 \% \mathrm{CO}_{2}$ treatment at $12{ }^{\circ} \mathrm{C}$ compared with those in both TR and MG mangoes at $12^{\circ} \mathrm{C}$, acetaldehyde and ethanol levels did not differ significantly in TR vs. MG fruit treatments (Table 1). This reflected the great variability in acetaldehyde and ethanol levels among the replicates in the TR $10 \%$ and $25 \% \mathrm{CO}_{2}$ treatments, which was probably related to differences in initiation of acetaldehyde and ethanol synthesis among the individual fruit. Acetaldehyde and ethanol levels were significantly higher in the TR mangoes from the $25 \% \mathrm{CO}_{2}$ treatment at $8^{\circ} \mathrm{C}$ than in the other TR fruit at $8{ }^{\circ} \mathrm{C}$ or in the TR fruit at $12{ }^{\circ} \mathrm{C}$ (Table 1 ). Pyruvate decarboxylase and alcohol dehydrogenase apparently were stimulated in the higher $\mathrm{CO}_{2}$ atmosphere, as observed by $\mathrm{Ke}$ et al. (1995) in avocados (Persea americana Mill.) stored under $\mathrm{CO}_{2}$ stress. Acetaldehyde and ethanol were highly correlated with "fermented" off-flavors in other fruits stored in stress levels of $\mathrm{O}_{2}$ and $\mathrm{CO}_{2}$ (Ke et al., 1994; $\mathrm{Ke}$ and Kader, 1990). Nevertheless, informal tasting of the mangoes from the present study did not indicate that the acetaldehyde and ethanol levels encountered had negatively affected the flavor of these fruit. Both acetaldehyde and ethanol are present in mango fruit at the beginning of ripening and before storage, and their levels normally increase during ripening, even in air (Bender, 1996).

Hexanal levels tended to be lower in TR mangoes in air or CA storage at $12{ }^{\circ} \mathrm{C}$ than in MG fruit stored in the same atmospheres (Table 1). Hexanal levels were also lower in TR mangoes stored at $8{ }^{\circ} \mathrm{C}$ than at $12^{\circ} \mathrm{C}$. Hexanal and C- 6 aldehydes impart a green flavor char- acter to preclimacteric apples (Flath et al., 1967; Willaert et al, 1983) and to fruit in general (Bauer et al, 1990). The higher concentrations of hexanal in the MG than in TR mangoes at $12^{\circ} \mathrm{C}$ are in agreement with those reports. However, the lower hexanal concentrations in TR mangoes stored at $8{ }^{\circ} \mathrm{C}$ than at $12^{\circ} \mathrm{C}$, is not in agreement with the observation that this flavor component is present in higher concentrations in less ripe fruit. If that were so, higher hexanal concentrations would be expected in the TR mangoes from $8^{\circ} \mathrm{C}$ storage, which were less ripe following storage than those stored at $12{ }^{\circ} \mathrm{C}$. However, in contrast with the situation reported for apples, hexanal levels increase during ripening of tomato (Lycopersicon esculentum Mill.) fruit (Baldwin et al., 1991).

\section{Conclusions}

Except for hexanal, aroma volatile levels after storage were greater in mangoes picked at the TR stage than in MG mangoes, regardless of storage atmosphere. Storing mangoes in a CA containing $10 \% \mathrm{CO}_{2}$ had little effect on aroma volatile levels compared with air storage, but an atmosphere containing $25 \%$ $\mathrm{CO}_{2}$ reduced terpene levels in both MG and TR fruit and increased acetaldehyde and ethanol levels in TR fruit. This sensitivity to high $\mathrm{CO}_{2}$ was greater in MG fruit than in TR fruit, and in TR fruit from $8^{\circ} \mathrm{C}$ storage than in those from $12{ }^{\circ} \mathrm{C}$ storage. While TR mangoes stored in $25 \% \mathrm{CO}_{2}$ produced elevated levels of acetaldehyde and ethanol, indicating that anaerobic metabolism was induced by the CA, their flavor was not impaired. In fact, aroma volatile levels were always higher in TR mangoes from both CA treatments than in either air- or CA-stored MG mangoes. The results show that $\mathrm{CA}$ storage, which prolongs mango shelf life by slowing the ripening processes, thus allowing TR mangoes to be successfully handled, also allows TR mangoes to be stored or shipped without sacrificing their superior aroma quality compared with MG fruit.

Table 1. Concentrations $\left(\mu \mathrm{L} \cdot \mathrm{L}^{-1}\right)$ or peak heights of volatiles in the headspace for mesocarp tissue from mature-green (MG) and tree-ripe (TR) 'Tommy Atkins' mangoes stored for $21 \mathrm{~d}$ in air or CA at 8 or $12{ }^{\circ} \mathrm{C}$ plus $2 \mathrm{~d}$ in air at $20^{\circ} \mathrm{C}$.

\begin{tabular}{|c|c|c|c|c|c|c|c|}
\hline Atmosphere & $\begin{array}{c}\alpha-\text { Pinene } \\
\left(\mu \mathrm{L} \cdot \mathrm{L}^{-1}\right)\end{array}$ & $\begin{array}{c}\text { 3-Carene } \\
\left(\mu \mathrm{L} \cdot \mathrm{L}^{-1}\right)\end{array}$ & $\begin{array}{c}\text { Limonene } \\
\left(\mu \mathrm{L} \cdot \mathrm{L}^{-1}\right)\end{array}$ & $\begin{array}{c}\text { p-Cymene } \\
\left(\mu \mathrm{L} \cdot \mathrm{L}^{-1}\right)\end{array}$ & $\begin{array}{l}\text { Acetaldehyde } \\
\text { (pk. ht in mm) }\end{array}$ & $\begin{array}{c}\text { Ethanol } \\
\text { (pk. ht in } \mathrm{mm} \text { ) }\end{array}$ & $\begin{array}{c}\text { Hexanal } \\
\text { (pk. ht in mm) }\end{array}$ \\
\hline \multicolumn{8}{|c|}{ MG mangoes at $12{ }^{\circ} \mathrm{C}$} \\
\hline Air & 2.56 & 18.6 & 0.30 & 0.03 & 1,322 & 780 & 361 \\
\hline $5 \% \mathrm{O}_{2}+25 \% \mathrm{CO}_{2}$ & 0.76 & 5.4 & 0.12 & 0.00 & 1,314 & 725 & 213 \\
\hline \multicolumn{8}{|c|}{ TR mangoes at $12^{\circ} \mathrm{C}$} \\
\hline Air & 7.92 & 63.3 & 1.32 & 0.09 & 1,498 & 2,822 & 165 \\
\hline \multicolumn{8}{|c|}{ TR mangoes at $8^{\circ} \mathrm{C}$} \\
\hline Air & 7.21 & 58.7 & 0.90 & 0.04 & 1,459 & 653 & 92 \\
\hline $5 \% \mathrm{O}_{2}+10 \% \mathrm{CO}_{2}$ & 5.86 & 53.5 & 1.03 & 0.04 & 1,577 & 1,249 & 29 \\
\hline $5 \% \mathrm{O}_{2}+25 \% \mathrm{CO}_{2}$ & 2.06 & 14.8 & 0.34 & 0.00 & 67,554 & 79,124 & 48 \\
\hline \multicolumn{8}{|c|}{$\operatorname{LSD}(P \leq 0.05)$} \\
\hline $\mathrm{MG}$ and $\mathrm{TR}$ at $12^{\circ} \mathrm{C}^{\mathrm{z}}$ & 3.12 & 25.3 & 0.48 & 0.06 & NS & NS & 104 \\
\hline
\end{tabular}

${ }^{2}$ Overall LSD at $P \leq 0.05$ for comparison of atmosphere treatments for MG and TR mangoes at $12{ }^{\circ} \mathrm{C}$.

${ }^{y}$ Overall LSD at $P \leq 0.05$ for comparison of atmosphere treatments for TR mangoes at 8 and $12{ }^{\circ} \mathrm{C}$.

NS Nonsignificant at $P \leq 0.05$. 


\section{Literature Cited}

Baldwin, E.A., M.O. Nisperos-Carriedo, and M.G. Moshanas. 1991. Quantitative analysis of flavor and other volatiles and for certain constituents of two tomato cultivars during ripening. J. Amer. Soc. Hort. Sci. 116:265-269.

Bartley, J.P. and A. Schwede. 1987. Volatile flavor components in the headspace of the Australian 'Bowen' mango. J. Food Sci. 52:353-360.

Bauer, K., D. Garbe, and H. Surburg. 1990. Common fragrance and flavor materials. $2^{\text {nd }} \mathrm{ed}$. $\mathrm{VCH}$, Weinheim/Germany.

Bender, R.J. 1996. Elevated $\mathrm{CO}_{2}$ in controlled atmosphere storage and regulation of mango ripening. PhD Diss., Hort. Sciences Dept., Univ. of Florida, Gainesville. (Diss. Abstr. AAG9800064)

Engel, K.H. and R. Tressl. 1983. Studies on the volatile components of two mango varieties. J. Agr. Food Chem. 31:796-801.

Flath, R.A., D.R. Black, D.G. Guadagni, W.H. McFadden, and T.H. Schultz. 1967. Identification and organoleptic evaluation of compounds in Delicious apple essence. J. Agr. Food Chem. 15:29-35.

Gholap, A.S. and C. Bandyopadhyay. 1980. Fatty acid biogenesis in ripening mango (Mangifera indica L. var. Alphonso). J. Agr. Food Chem. 28:839-841.

Gourgue, C.M.-P., M.M.-J. Champ, Y. Lozano, and J.D. Laval. 1992. Dietary fiber from mango byproducts: Characterization and hypoglycemic effects determined by in vitro methods. J. Agr. Food Chem. 40:1864-1868.

Ke, D. and A.A. Kader. 1990. Tolerance of 'Valencia' oranges to controlled atmospheres as determined by physiological responses and quality attributes. J. Amer. Soc. Hort. Sci. 115:779-783.

Ke, D., F. El-Wazir, B. Cole, M. Mateos, and A.A. Kader. 1994. Tolerance of peach and nectarine fruits to insecticidal controlled atmospheres as influenced by cultivar, maturity, and size. Postharv. Biol. Technol. 4:135-146.

Ke, D., E. Yahia, B. Hess, L. Zhou, and A.A. Kader. 1995. Regulation of fermentative metabolism in avocado fruit under oxygen and carbon dioxide stresses. J. Amer. Soc. Hort. Sci. 120:481-490.

Koulibaly, A., M. Sakho, and J. Crouzet. 1992. Variability of free and bound volatile terpenic compounds in mango. Lebens. Wiss. Technol. 25:374-379.

Lakshminarayana, S. 1980. Mango, p. 184-257. In: S. Nagy and P.E. Shaw (eds.). Tropical and subtropical fruits. Composition, properties and uses. AVI, Westport, Conn.

MacLeod, A.J. and C.H. Snyder. 1985. Volatile components of two cultivars of mango from Florida. J. Agr. Food Chem. 33:380-384.

Malundo, T.M.M., E.A. Baldwin, G.O. Ware, and R.L. Shewfelt. 1996. Volatile composition and interaction influence flavor properties of mango (Mangifera indica L.). Proc. Fla. State Hort. Soc. 109:264-268.

Malundo, T.M.M., E.A. Baldwin, M.G. Moshonas, R.A. Baker, and R.L. Shewfelt. 1997. Method for the rapid headspace analysis of mango (Mangifera indica L.) homogenate volatile constituents and factors affecting quantitative results. J. Agr. Food Chem. 45:2187-2194.

Medlicott, A.P., M. Bhogol, and S.B. Reynolds.
1986. Changes in peel pigmentation during ripening of mango fruit (Mangifera indica var. Tommy Atkins). Ann. Appl. Bot. 109:651656.

Miller, W.R., D.H. Spalding, and P.W. Hale. 1986. Film wrapping mangos at advancing stages of post-harvest ripening. Trop. Sci. 26:9-17.

Selvaraj, Y., R. Kumar, and D.K. Pal. 1989. Changes in sugars, organic acids, amino acids, lipid constituents and aroma characteristics of ripening mango (Mangifera indica L.) fruit. J. Food Sci. Technol. 26:308-313.

Streif, J. and F. Bangerth. 1988. Production of volatile aroma substances by 'Golden Delicious' apple fruits after storage for various times in different $\mathrm{CO}_{2}$ and $\mathrm{O}_{2}$ concentrations. $\mathrm{J}$. Hort. Sci. 63:193-199.

Subrahmanyam, K.U. 1990. International trade in mango: India's role. Acta Hort. 269:89-95.

Thomas, P. and M.R. Joshi. 1988. Reduction of chilling injury in ripe 'Alphonso' mango fruit in cold storage by temperature conditioning. Intl. J. Food Sci. Technol. 23:447-455.

Tucker, G.A. and G.B. Seymour. 1991. Cell wall degradation during mango fruit ripening. Acta Hort. 291:454-471.

Willaert, G.A., P.J. Dirinck, H.L. De Pooter, and N.N. Schamp. 1983. Objective measurement of aroma quality of Golden Delicious apples as a function of controlled-atmosphere storage time. J. Agr. Food Chem. 31:809-813.

Wilson, C.W., III, P.E. Shaw, and R.J. Knight, Jr. 1990. Importance of some lactones and 2,5dimethyl-4-hydroxy-3(2H)-furanone to mango (Mangifera indica L.) aroma. J. Agr. Food Chem. 38:1556-1559. 